\title{
KORUMA BAKIŞ AÇISIYLA EL YAZMALARINDA GÖRÜLEN BIYODETERASYON***
}

\author{
Conservation Overview of Biodeteration in Manuscripts
}

Aybuke Sultan KOCA YILMAZ1, Ali Akın AKYOL ${ }^{2}$, Hikmet KATIRCIOĞLU ${ }^{3}$

\begin{abstract}
ÖZET
İnsanlık tarihinin büyük bir kısmı, yazılı belgeler veya sanat eserleri üzerinden izlenebilmektedir. Bu mirasın çok önemli bir bölümünü ise zengin bir organik malzeme grubuna sahip arşivler ve kütüphaneler oluşturmaktadır. Organik malzemeler doğaları gereği bozulmalara oldukça açıktırlar. Bozulma türlerinden biri olan biyodeterasyon ise bunların içinde önemli bir yüzdeyi oluşturmaktadır. Biyodeterasyona neden olan ve biyolojik ajan olarak da adlandırılan; biyodeterojenlerdir. Kemirgenler, böcekler gibi makro-biyodeterojenler tam olarak ortadan kaldırılabilirken; fungus, bakteri gibi mikro-biyodeterojenler üzerinde çalışmalar halen devam etmektedir. Araștırma kapsamında elde edilen mikro-biyodeterojen sonuçlarının konservasyon çalışmalarına katk1 sağlaması amaçlanmıștır. Vakıflar Genel Müdürlüğü Ankara Kültür ve Tescil Daire Başkanlığı'nda muhafaza edilen Safranbolu El Yazmaları Koleksiyonu durum taramasindan geçirildikten sonra Mushaf-1 Şerifler'den üç eser mikrobiyodeterojen çeşitliliğinin tespiti için çalışma kapsamına alınmıştır. Seçilen eserlerden elde edilen kültürler ile arşiv odası mikroflorası karşılaştırılmıștır. Temel amaç arşiv odasının mikroflorasının yoğunluğunun eserler üzerinde oluşturacağı potansiyel biyodeterasyonun tespitidir. Buna ek olarak seçilen eserlerden elde edilen kültürler ile kompakt raylı raf sistemi mikroflorası da karşılaştırılmıştır. Burada ki temel amaç ise eserler arasında bir mikroflora yayılımının kontrol edilmesidir. Araştırma kapsamında Mucor sp., Penicillum sp., Aspergillus sp., Rhizopus sp., Trichoderma sp. cinsi küfler ile Bacillus sp, Pseudonomas sp. Micrococcus sp. ve Escherichia sp. cinsi bakteriler izole edilerek konservasyon alanında mikrobiyodeterojen çeşitliliğine katkı sağlanmıştır.
\end{abstract}

Anahtar Kelimeler: El yazmaları, konservasyon, biyodeterasyon, fungus, bakteri.

\begin{abstract}
A great part of human history can be traced through written documents or works of art. Archives and libraries with a rich organic material group constitute a very important part of this heritage. Organic materials are very prone to deterioration due to their nature. Biodeterioration, which is one of the types of disruption, constitutes an important percentage among them. It is these biodeterogens, also called biological agents that cause biodeterioration. While macro-biodeterogens such as rodents and insects can be completely eliminated; studies on microbiodeterogens such as fungi and bacteria are still ongoing. Microbiodeterogens results obtained within the scope of our study are aimed to contribute to molecular and conservation studies. After the Safranbolu Manuscripts Collection kept in the General Directorate of Foundations Ankara Culture and Registration Department was subjected to the status screening, three manuscripts from Mushaf-1 Şerifler were included in the study for the determination of micro-biodeterogens diversity. The cultures obtained from the selected manuscripts were compared with the archive room microflora. The main purpose is to determine the potential biodeterioration that the density of the microflora of the archive room will create on the manuscript. In addition, the isolate from selected manuscript and the microflora of the compact rail rack system were compared. The main purpose here is to control the microflora spread among the manuscript. In conclusion, Mucor sp., Penicillum sp., Aspergillus sp., Rhizopus sp., Trichoderma sp. genus molds with Bacillus sp, Pseudonomas sp. Micrococcus sp. and Escherichia sp. genus bacteria were isolated and a contribution was made to micro- biodeterogens diversity in the conservation area.
\end{abstract}

Keywords: Manuscript, conservation, biodeterioration, fungi, bacteria.

\section{ORCID: 0000-0002-7442-3220 \\ 2. ORCID: 0000-0002-4174-575X \\ 3. ORCID: 0000-0002-4866-6106}

1. Doktora Öğrencisi, Ankara Hacı Bayram Veli Üniversitesi, Lisansüstü Eğitim Enstitüsü, Kültür Varlıklarını Koruma Anabilim Dalı, aybuke.koca@hbv.edu.tr

2. Doçent, Ankara Hacı Bayram Veli Üniversitesi, Güzel Sanatlar Fakültesi, Kültür Varlıklarını Koruma ve Onarım Bölümü, ali.akyol@hbv.edu.tr

3. Profesör, Gazi Üniversitesi, Gazi Eğitim Fakültesi, Biyoloji Eğitimi Anabilim Dalı, hturk@gazi.edu.tr

* Koca Yılmaz, A. S., Akyol, A. A., Katırcıoğlu, H. (2020). Koruma Bakış Açısıyla El Yazmalarında Görülen Biyodeterasyon. Akademik Sanat, 5(11), 1-17.

** Bu çalışma 24-25 Haziran 2020 tarihli Uluslararası Genç Bilim ve Sanat İnsanları Sempozyumu'nda bildiri olarak sunulmuştur. 


\section{EXTENDED ABSTRACT}

Most of human history is recorded in the form of paper-backed documents or artwork. These organic records form a group of materials that are very prone to deterioration. Biodeterioration, which is one of the types of disruption, constitutes an important percentage among them. It is these biodeterogens, also called biological agents that cause biodeterioration. While macro- biodeterogens such as rodents and insects can be completely eliminated; studies on micro- biodeterogens such as fungi and bacteria are still ongoing. Microflora results obtained within the scope of our study are aimed to contribute to molecular studies and conservation studies.

After the Safranbolu collection, which was kept at the Ankara Directorate of Culture and Registration Department of the General Directorate of Foundations, under the condition screening, three manuscripts of Mushaf-i Sharif were included in the study. The microflora of the archive room was compared with the isolate obtained from the selected manuscripts. The main purpose is to determine the potential biodeterioration that the density of the microflora of the archive room will create on the manuscript. In addition, the isolate from selected manuscript and the microflora of the compact rail rack system were compared. The main purpose here is to control the microflora spread among the manuscript.

Within the scope of the study, Nutrient Agar (NA) and Potato Dextrose Agar (PDA) petri dish was placed in various parts of the archive room (in front of the windows, on the door opening, on the cabinet, inside the cabinet and on the shelf where the manuscripts was taken) and sports were collected from the air for 45 minutes. Samples were taken from the contact surfaces of the manuscript stored in a compact rail system (the outer and upper surfaces of the shelf where the other manuscript are related) with a sterile swab application method. Since the manuscripts are very fascicular, they are taken from the cover and also 3 different pages. A sample of sterile swab was taken from the manuscript. These 24 samples in total were brought to the laboratory in saline solution.

Identification studies were supported by using general and selective media in microflora detection. Petri dishes containing samples collected from the air of the archive room were left to incubate (in development environment) at $30^{\circ} \mathrm{C}$ for $24-48$ hours. Due to the fact that microorganisms in the samples taken from sterile swabs with application method from compact racks and manuscript have been dormant for a long time, Nutrient Broth (NB) and Yeast Extract Peptone Dextrose (YEPD) Broth at media were enriched. After 48 hours of activation, samples from Nutrient Broth (NB) were transferred to Nutrient Agar (NA), Eosin Methylene Blue (EMB) and Pseudonomas Agar F Base medium for identification; Yeast Extract Peptone Dextrose (YEPD) Broth was transferred to Potato Dextrose Agar (PDA) medium for identification.

Samples left for incubation at $30^{\circ} \mathrm{C}$ were first categorized by taking into consideration the colony morphologies. Then, single colony was cultivated and left for incubation at $30^{\circ} \mathrm{C}$. Preparations from the observed bacterial colonies were prepared; gram staining was done and examined under immersion lens under light microscope. Preparations were also prepared from isolates with fungus and examined under a light microscope.

As a result of the macroscopic examination of all bacterial isolates, it was determined that there were 22 different colonies in Nutrient Agar (NA) medium, 13 different colonies in Pseudonomas Agar F Base Media and 3 different colonies in Eosin Methylene Blue (EMB) Media. When evaluated according to the pigment production, it was determined that there are 9 different color pigment production, 21 of which are smooth (S-Type), 23 of which have rough (R-Type) edge type colony morphology according to the edge type. According to the results of gram staining, 16 isolates were found to be bacillus, 3 isolates to be coccus, and 2 isolates to be streptobacillus. In addition, it was concluded that 9 were gram negative and 13 were gram positive.

When fungal isolates were examined, fungal colonies were identified in 11 isolates. Vegetative hyphic structure without septa was detected in 4 of the isolates and vegetative hyphae structure with septa in 7. In addition, sporangium fertile hif structure was detected in 2 of the isolates and conidia-type fertile hif structure in 9 of the isolates.

In conclusion, Mucor sp., Penicillum sp., Aspergillus sp., Rhizopus sp., Trichoderma sp. genus molds with Bacillus sp, Pseudonomas sp. Micrococcus sp. and Escherichia sp. genus bacteria were isolated and a contribution was made to micro- biodeterogens diversity in the conservation area. 


\section{GİRIȘ}

Bilgi, yazının keşfi ile birlikte nesilden nesile aktarılabilmiştir. Bilginin aktarıldığı üç boyutlu düzlem zamanla değişim göstermiş kağıdın keşfiyle birlikte son halini almıştır. Matbaanın ortaya çıkışına kadar kağıda elle yazılmış, matbaanın keşfiyle birlikte yerini basma eserlere bırakmıştır.

Yazma eserlerde kullanılmış olan kağıtlar doğaları gereği bozulmaya oldukça açık bir malzeme grubunu oluşturmaktadırlar. Yazma eserlerde kağıdın organik yapısının yanı sıra; sırt dikişinde kullanılan iplik, aharlamada kullanılan nişasta ve jelatin, ciltlemede kullanılan tutkal, murakka, deri gibi diğer malzemeler de biyodeterojenler ${ }^{1}$ açısından zengin besiyeri ortamı oluşturmaktadır.

Bu nedenle dünyanın dört bir yanında, arşiv ve koleksiyonlara sahip olan kütüphaneler, biyolojik tehditler ile karşı karşıya kalmaktadırlar. Bozulmalara engel olabilmek için çeşitli önleyici koruma (1s1, sıcaklık, 1şık, nem vb.) yöntemleri uygulanmaktadır (Baydar, 2001, s. 367-370). Bu alandaki etkin koruma çalışmaları ise kağıdın üretildiği ilk zamanlarda başlamış olup, zaman içinde evrilerek ve gelişerek devam etmiştir. İlk dönemlerde parşömen ve papirüsten yapılan kodeks ve rulo kitapların neme ve biyolojik tahribata karşı korunmasında değişik bitki suları ile yıkama, fildişi ya da ahşap sandıklar içinde saklama, bazen de böcek öldürücü (pestisit) mürekkeplerle kitapların içlerine çeşitli dualar yazma gibi yöntemlerin uygulandığı görülmektedir (Kathpalia, 1990, s. XXXIII, XXXIV). Devam eden süreçte çeşitli yöntemler, kullanışsızlığ 1 nedeniyle terk edilmiş; çeşitli yöntemler ise kullanışlı1ık açısından halen tartışma konusu olmuştur (Koca-Yılmaz, 2019, s. 14-18). Fakat kesin olan bir sonuç vardır ki; o da mikrobiyolojik bozulmaya henüz net bir çözüm getirilememiştir.

Kağıdın ana maddesi olan selüloz, Anselme Payen tarafından 1839'da izole edilmiştir (Wisniak, 2005, s. 124,125; Heldt ve Piechulla, 2011, s. 4; Chen, 2014, s. 29). Selüloz molekülünde kristalin ve amorf bölgeler bulunmaktadır (Resim 1). Bu bölgelerin yüzdece dağılımı kağıdın dayanıklılı̆̆ı açısından önem teşkil etmektedir. Zira amorf bölge kristalin bölgesine göre daha kolay bozulmaya uğramaktadır. Amorf bölgelerin yüzdece fazla olması kağıdın dayanıklılı̆̆ın az olduğunun göstergesi kabul edilmektedir (Perez vd., 2002, s. 54; Khazraji ve Robert, 2013, s. 2).

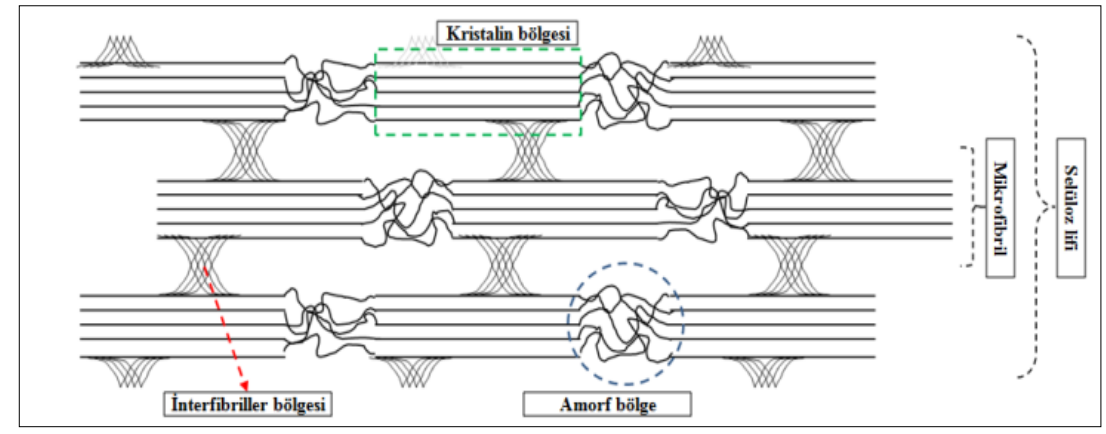

Resim 1. Selülozun kristalin ve amorf bölge yapısı (Börjesson ve Westman, 2015, s.163)

Selüloz molekülü abiyotik faktörler kadar biyotik faktörler nedeniyle de deterasyona; ilerleyen süreçte ise degradasyona uğrayabilmektedir. Selülozun parçalanmasını sağlayan enzimleri üreten çok sayıda mikroorganizma bulunmaktadır. Fakat bunlardan birkaçı, kristalin selülozun degradasyonu için gerekli olan tüm enzim sistemine sahiptir (Beguin ve Aubert, 1994, s. 29; Kuhad vd., 2007, s. 5).

\section{Kağıtta Görülen Biyodeterasyon ve Biyodegradasyon}

Hueck tarafından (1965-1968) biyodeterasyon (biyobozulma) terimi; "Bir materyalin ana bileşenlerinde, organizmaların canlılık aktivitelerinden kaynaklı istenmeyen değişiklikler" olarak tanımlanmıştır (Alexander ve Schiesser, 2017, s. 182). Benzer şekilde Rose (1981) tarafindan ortaya atılan biyodeterasyon terimi ise; "Biyolojik ajanların yani canlı organizmaların yapısal değer veya kalitede meydana getirdiği değişiklikler" olarak tanımlanmıştır (Sanchez-Silva ve Rosowsky, 2008, s. 353). Biyodegradasyon ve biyodeterasyon terimleri birbirinden farklı terimler olmasına rağmen yanlış bir alg1 olarak eş anlamlı gibi düşünülmektedir. Biyodegradasyon (biyobozunma) terimi mikroorganizmaların yaşamsal faaliyetlerini sürdürmek adına tam

\footnotetext{
${ }^{1}$ Biyodeterojenler; biyodeterasyona neden olan biyolojik ajanları ifade etmektedir.
} 
parçalanmayı ifade ederken; biyodeterasyon terimi mikroorganizma kaynaklı materyaldeki fiziksel değişimi ifade etmektedir. Bu iki terim birbirinden çok ince nüanslar ile ayrılmaktadır (Koca-Yılmaz vd., 2020, s. 44).

Biyokimyasal deterasyon, biyodeterasyonun en karmaşık şeklidir ve biyodeterojenlerin metabolik işlemleri sonucu ürettiği metabolitlerin materyal üzerindeki etkisi ile ortaya çıkmaktadır. Biyodeterojenlerin ürettiği metabolitler nedeniyle ana materyal dokusu zayıflamakta ve bu bölgelerde bozulma için daha elverişli koşullar ortaya çıkmaktadır. Böylece bozulma işlemi artarak devam etmektedir (Alexander ve Schiesser, 2017, s. 183). Arkeler, likenler, algler, siyanobakteriler, kemolitotrofik bakteriler, kemoorganotrofik bakteriler ile funguslar gibi farklı filogenetik mikroorganizma grupları, biyodeterojenleri oluşturmaktadır (Michaelsen, 2010, s. 9). Fakat bunun yanı sıra ister müze içinde sergilenen veya depolanan isterse açık havada sergilenen tüm kültür varlıklarında bozulmaya neden olan makroorganizma grupları da (kemirgenler, kuşlar, bitkiler, böcekler vb.) biyodeterojen tanımı içine girmektedir (Carlo vd., 2017, s. 2).

Kağıtta görülen biyodeterasyonun iki ana kontaminasyon (kirlilik) kaynağı bulunmaktadır. Bunlardan ilki kağıdın yapım aşamasında kullanılan malzeme ve yöntem kaynaklı (Akkayan, 1987, s. 109; Kathpalia, 1990, s. 2-4; Sterflinger ve Pinzari, 2012, s. 563); ikincisi ise aktif kullanım esnasında çevre koşulları, insan faktörü ve yanlış depolama kaynaklı kontaminasyonlardır (Akkayan, 1987, s.120; Hagaggi ve Salah, 2016, s. 65; Karakasidou vd., 2017, s. 2). Biyolojik kirlenmeye neden olan bu mikroorganizmalar havada rahatlıkla asılı kalabilmekte ve taşınabilmektedir (Ünlü-Yokuş, 2018, s. 12).

Çok çeşitli mikroorganizma grupları kağıtta mikrobiyolojik bozulmalara (biyodeterasyon) neden olan enzimleri üretebilmektedir. Bu mikroorganizma gruplarından üzerinde en çok çalış1lanları ise Aspergillus sp., Penicillium sp. ve Trichoderma sp. cinsi funguslar ile Bacillus sp., Clostridium sp., Pseudomonas sp. ve Micrococcus sp. cinsi bakterilerdir (Gallo, 1953, s. 3; Beguin, 1990, s. 227-229; Rojas vd., 2002, s. 193; Sterflinger ve Pinzari, 2012, s. 563; Karakasidou vd., 2017, s. 2; Ruiz vd., 2018, s. 1).

Fungus bulaştı̆̆ bölgede bir deterasyon (kabarıklık, pamuklaşma) meydana getirmektedir (Nianping vd., 2011, s. 394; Hagaggi ve Salah, 2016, s. 65). Bozulan bu kağıt liflerinde gerçekleşen bir dizi reaksiyon sonucu; kırmızıkahverengimsi lekelenmeler şeklinde kendini gösteren ve literatürde "foxing" olarak bilinen bozulma türü ortaya çıkmaktadır (Pinar vd., 2013, s. 105; Sterflinger ve Pinar, 2013, s. 9640). Maillard reaksiyonu olarak da bilinen kahverengileşme reaksiyonuna fungus kaynaklı serbest oligosakkaritler ile amino asitlerin etkileşiminin neden olduğu düşünülmektedir. Kırmızımsı lekeye ise selüloz oksidasyonu sonucu ortaya çıkan karbonil grubu ile aminokarboksilin ve/veya havada bulunan kirleticilerin reaksiyonlarının neden olduğu düşünülmektedir (Michaelsen, 2010, s. 13; Koca-Yılmaz, 2019, s. 13). Son yıllarda "foxing" lekelenmelerine fungusların yanı sira demir, bakır, kobalt gibi çeşitli metallerin, bakterilerin, organik ve inorganik asitlerin selüloz oksidasyonu ile verdikleri tepkimelerin de neden olduğu yapılan çalışmalar ile raporlandırılmıştır (Michaelsen, 2010, s. 14- 20; Sterflinger ve Pinar, 2013, s. 9640; Dunca vd., 2014, s. 247).

\section{Materyal ve Metod}

Safranbolu'dan Ankara Kültür ve Tescil Daire Başkanlığı'na getirilen el yazması Mushaf-1 Şerifler bu çalışmada örneklemi oluşturmuştur. Arşiv odasındaki durum taraması sonucunda Mushaf-1 Şeriflerden mikrobiyolojik bozulmayı en iyi gösteren 3 eser seçilmiştir (Resim 2, Tablo 1).

\begin{tabular}{|c|c|c|c|c|}
\hline \multirow{2}{*}{ Arşiv No } & Koleksiyon Adı & \multicolumn{2}{c|}{ Eser Adı } & Nev'i \\
\hline $\mathbf{7 5 6}$ & Safranbolu & Mushaf-1 Şerif & Yazma & - \\
\hline $\mathbf{7 5 9}$ & Safranbolu & Mushaf-1 Şerif & Yazma & 1233 \\
\hline $\mathbf{7 7 3}$ & Safranbolu & Mushaf-1 Şerif & Yazma & - \\
\hline
\end{tabular}

Tablo 1. Örneklemi oluşturan demirbaş eserler 

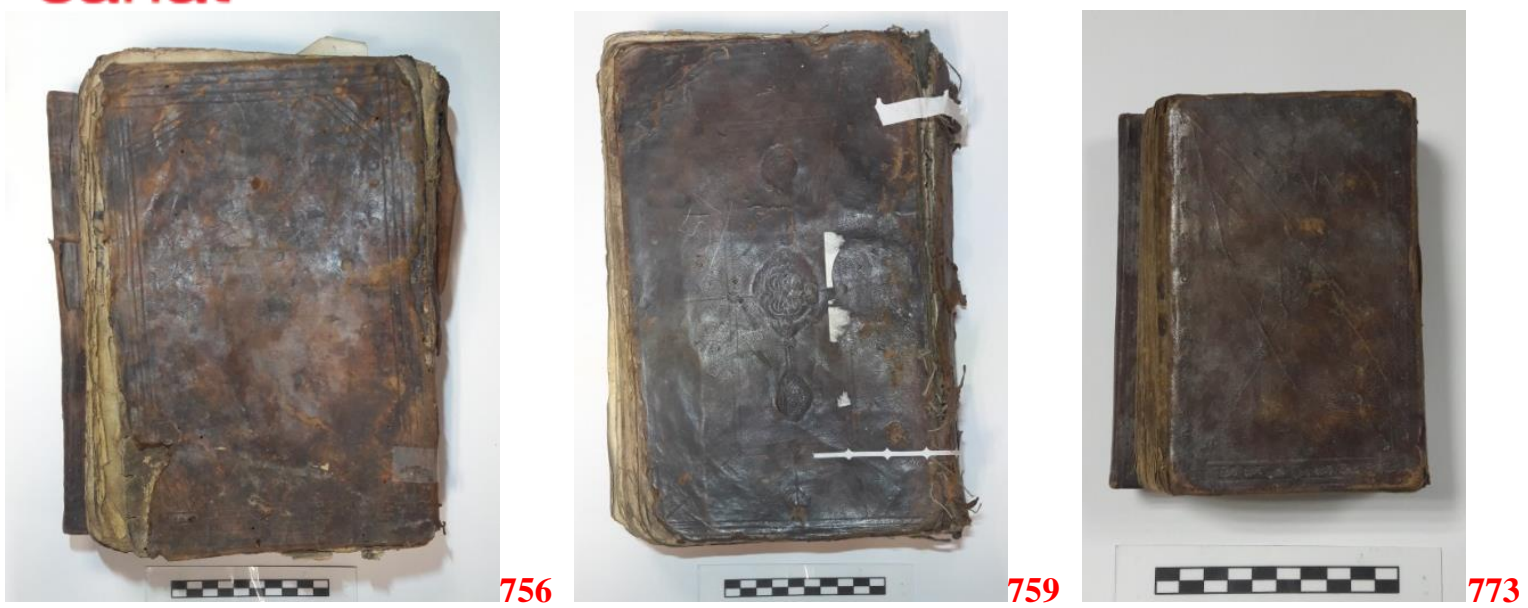

Resim 2. Safranbolu'dan Kültür ve Tescil Daire Başkanlığı'na getirilen Mushaf-1 Şeriflerden biyodeterasyon analizi yapılacak eserler

Eserlerin seçiminde nem tahribatı öncelikli bozulma alanı olarak belirlenmiş;; ardından 756 arşiv numaralı eser pamuklaşma tespit edildiği; 759 arşiv numaralı eser yaygın foxing görüldüğü ve 773 arşiv numaralı eser cetvel kırı̆̆g olduğu için araştırmaya dahil edilmiştir (Resim 3).
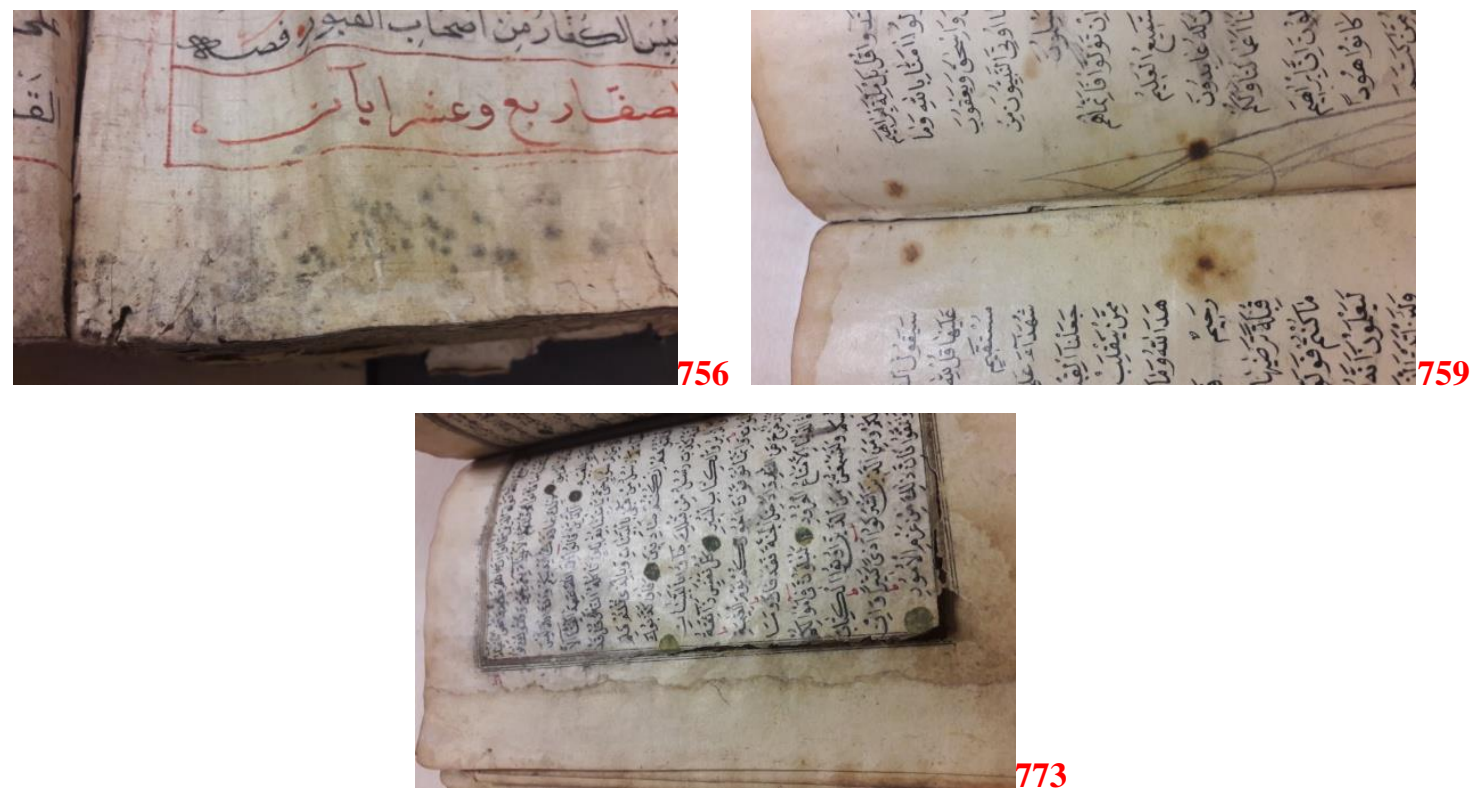

Resim 3. Çalışma kapsamında ele alınan eserlerin bozulma durumları

\subsection{Araştırmada Kullanılan Besiyerleri ve Çözeltiler}

Mikrobiyolojik analizlerin en önemli aşamalarından birisi uygulanacak analiz yöntemine göre kullanılacak besiyerlerinin seçilmesidir. Besiyerleri (sıv1/katı/yarı katı) kullanım amaçlarına göre genel amaçlı veya selektif (ayırt edici) özellikte olması gerekmektedir.

Genel besiyeri; besin maddelerince yeterince zengin, herhangi bir mikroorganizma grubunun (zor gelişenler de dahil) gelişmesini özel olarak desteklemeyen veya engellemeyen besiyerleridir. $\mathrm{Bu}$ grupta değerlendirilen besiyerleri genel olarak bakteriler için kullanılsa da bu besiyerinde maya ve küfte gelişebilmektedir (Halkman, 2005, s. 30). Selektif besiyeri karışık bir mikrobiyal floradan gelişmesi istenmeyenleri baskılamak; gelişmesi istenenleri açığa çıkarmak üzere üretilmiş besiyerleridir (Halkman, 2005, s. 31).

Mikroorganizmalar izole edildikten sonra laboratuara serum fizyolojik (\% $0,09 \mathrm{NaCl}$ ) çözeltisi içerisinde taşınmıştır. Fungus için zenginleştirme ortamı olarak Yeast Extract Peptone Dextrose (YEPD) broth besiyeri tanımlama için Potato Dextrose Agar (PDA) kullanılmıştır. Bakteri zenginleştirme ortamı için ise Nutrient Broth (NB) tanımlama için genel besiyeri olarak Nutrient Agar (NA), seçici besiyeri olarak ise Eosin methylene Blue (EMB) Agar ve Pseudonomas Agar F Base besiyerleri kullanılmıştır. 


\subsection{Eserlerden Mikroorganizmaların İzolasyonu}

Mikroorganizma izolasyonunun temel basamağı koloni elde edilmesidir. Eserlerden izolasyon yapılırken dikkat edilmesi gereken en önemli husus, tahribatsız örnek alınmasının gerekliliğidir (Michaelsen vd., 2009, s. 162). Koloni eldesi çalışma kapsamında arşiv odasının havasından (Resim 4, Tablo 2); eserin depolandığı kompakt raylı raf sitemi içinde eserle temas eden yüzeylerden (diğer eser ve alt-üst raf) (Resim 5, Tablo 3) ve ayrıca eserin kendisinden ${ }^{2}$ (Resim 6, Tablo 4) izole edilerek gerçekleştirilmiştir.
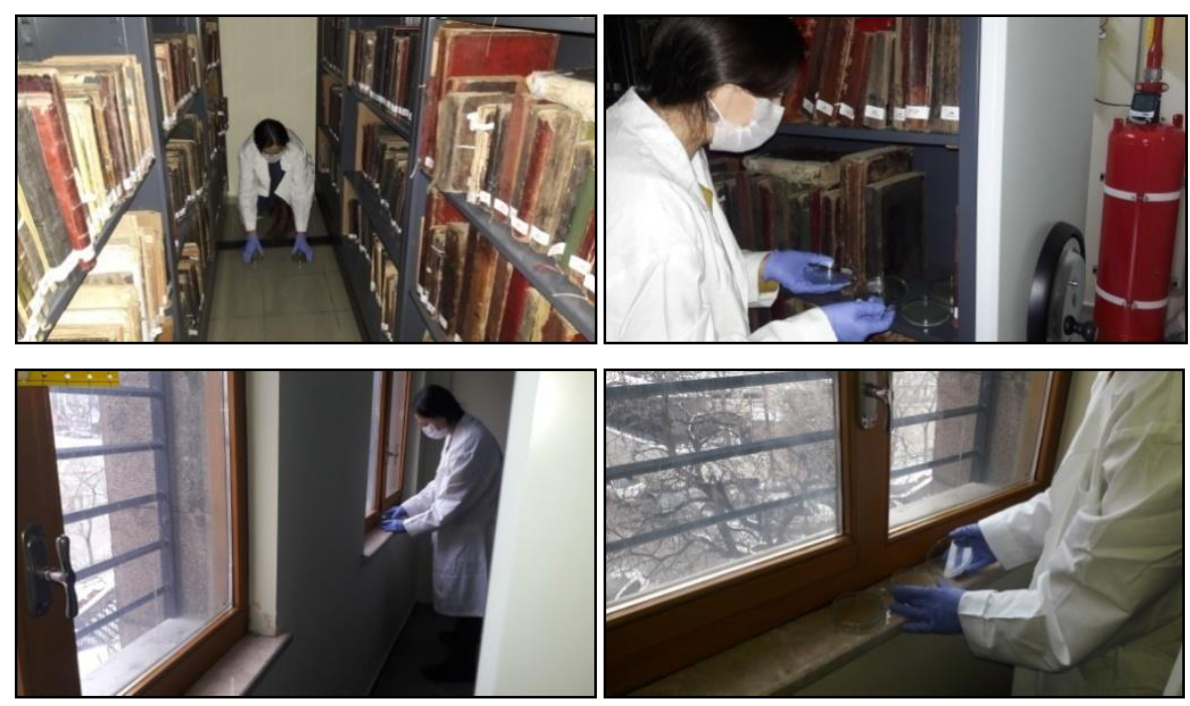

Resim 4. Arşiv odasında havadan örnek toplanması işlemi

\begin{tabular}{|c|c|}
\hline Örnek No & Örneklem Yeri \\
\hline P-1 & Pencere önü 1 \\
\hline P-2 & Pencere önü 2 \\
\hline DÜ-1 & Dolap üstü \\
\hline Di்-1 & Dolap içi \\
\hline R-1 & Raf \\
\hline KA-1 & Kapı ağZı \\
\hline
\end{tabular}

Tablo 2. Arşiv odasında havadan alınan örneklerin listesi
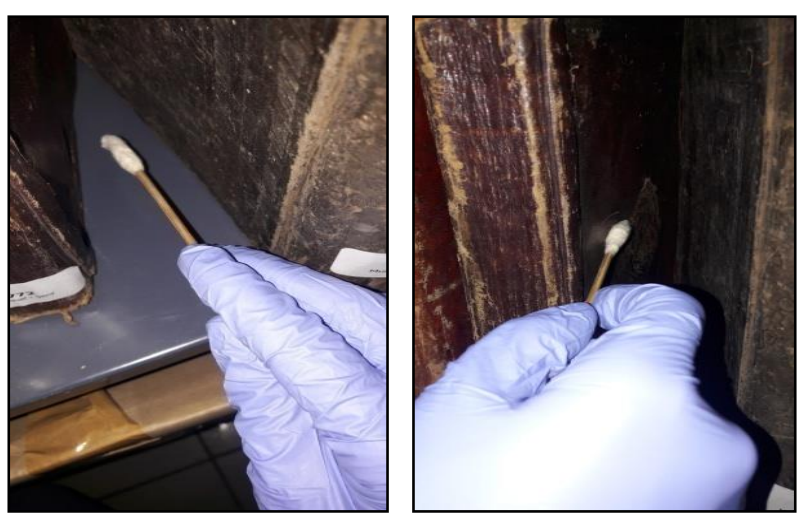

Resim 5. Arşiv odasında eserlerin temas yüzeylerinden örnek toplanması işlemi

\footnotetext{
${ }^{2}$ Eserler çok fasiküllü olduğu için, bozulma durumlarını göz önüne alınarak sayfa sayfa incelenmiş ve eserin 3 farklı noktasından örnek alınmıştır.
} 


\begin{tabular}{|c|c|c|}
\hline Arşiv No & Örnek Kodu & Örneklem Yeri \\
\hline \multirow{2}{*}{756} & A-K & 755 üst kap -757 alt kap \\
\hline & A-R & Alt - üst raf \\
\hline \multirow{2}{*}{759} & A-K & 758 üst kap -760 alt kap \\
\hline & A-R & Alt - üst raf \\
\hline \multirow{2}{*}{773} & A-K & 772 üst kap -774 alt kap \\
\hline & A-R & Alt - üst raf \\
\hline
\end{tabular}

Tablo 3. Kompakt raylı raf sistemi içerisinden alınan örneklerin listesi

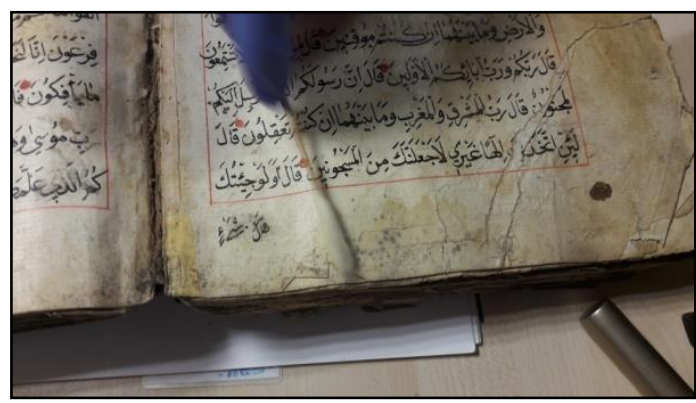

Resim 6. Steril eküvyon çubuk ile tahribatsız örnek alma

\begin{tabular}{|c|c|c|}
\hline Arşiv No & Örnek Kodu & Örneklem Yeri \\
\hline \multirow{4}{*}{756} & E-1 & İç sayfa 1. örnek \\
\hline & E-2 & İç sayfa 2. örnek \\
\hline & E-3 & İç sayfa 3. örnek \\
\hline & E-K & Örneğin alt üst kab1 \\
\hline \multirow{4}{*}{759} & E-1 & İç sayfa 1. örnek \\
\hline & E-2 & İç sayfa 2. örnek \\
\hline & E-3 & İç sayfa 3. örnek \\
\hline & E-K & Örneğin alt üst kab1 \\
\hline \multirow{4}{*}{773} & E-1 & İç sayfa 1. örnek \\
\hline & E-2 & İç sayfa 2. örnek \\
\hline & E-3 & İç sayfa 3. örnek \\
\hline & E-K & Örneğin alt üst kab1 \\
\hline
\end{tabular}

Tablo 4. Koloni eldesi kapsamında Mushaf-1 Şerif’lerden alınan örnek listesi

Örnek içeren eküvyon çubukları içinde $5 \mathrm{ml}$ steril serum fizyolojik çözeltisi bulunan tüplere konulmuştur. Tüplerin ağzı alevden geçirilip parafilmlenerek laboratuvara taşınmıştır (Resim 7).

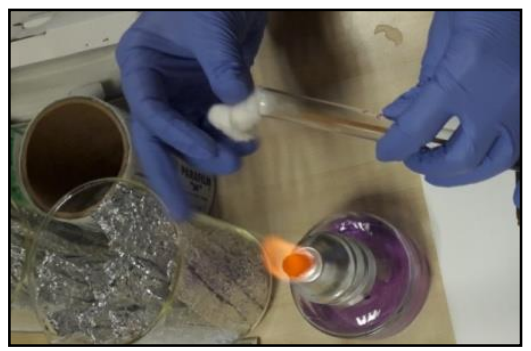

Resim 7. Tüplerin ağzınının alevden geçirilme işlemi

Laboratuvara getirilen örnekler ilk olarak 3000 rpm'de 30 saniye boyunca vortekslenmiştir. Böylece eküvyon çubuğunda bulunan örneğin serum fizyolojiğe geçmesi sağlanmıştır. Daha sonra laminar flow (steril kabin) içerisinde serum fizyolojik süspansiyonundan 100 'er $\mu$ l mikropipetle çekilerek zenginleştirme besiyeri olan NB ve YEPD broth besiyerlerine aktarılmış $30^{\circ} \mathrm{C}$ 'de $24-48$ saat inkübasyona birakılmıştır. Zenginleştirme sonrası NB besiyerinden steril öze ile alınan örnekler sürme metodu ile genel besiyeri olan NA; selektif besiyerleri olan EMB 


\section{sanat}

ve Pseudonomas agar F base'e aktarılmıştır. YEPD broth besyerinden aynı yöntemle alınan örnekler ise PDA besiyerine aktarılmıştır. Tüm örnekler yeniden $30^{\circ} \mathrm{C}$ 'de $24-48$ saat inkübasyona bırakılmıştır.

\section{Bulgular}

\subsection{Arşiv Odası Bakteri Örnekleri Koloni Morfolojisi Sonuçları}

Arşiv odasının mikroflorasını belirlemek amacıyla odanın çeşitli bölgelerine (Tablo 2) yerleştirilen petri kapları ile kompakt raylı raf sistemi içerisinde eserlerle doğrudan temas eden yüzeylerden (Tablo 3) eküvyon çubuklar ile alınan örneklerin NA besiyerinde üremeleri görsel olarak incelenmiş (Resim 8) ve toplamda 10 farklı koloni tespit edilmiştir (Tablo 5).

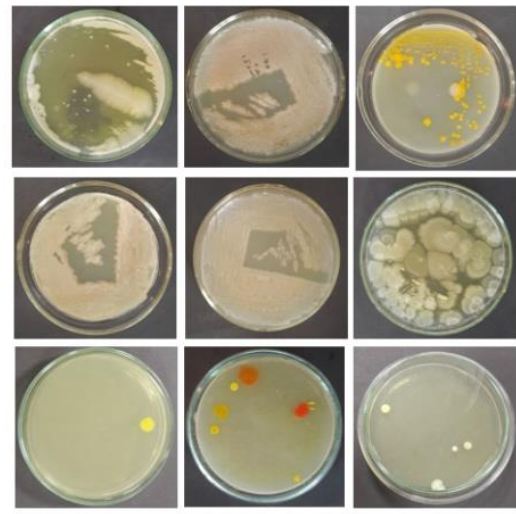

Resim 8. NA besiyerinde; 756-A-K, 759-A-K, 759-A-R (birinci sıra soldan sağa); 773-A-K, 773-A-R, P1 (ikinci sıra soldan sağa); P2, DÜ-1, K-1 (üçüncü sıra soldan sağa) görsel koloni morfolojisi

\begin{tabular}{|c|c|c|c|c|c|}
\hline Örnekler & Koloni Çeşidi & Form & Kenar Tipi & Yükseklik & Rengi \\
\hline 756-A-K & 1 & Düzensiz ve yayılıcı & $\mathrm{R}$ & Kabarık & Krem \\
\hline 759-A-K & 1 & Buruşuk & $\mathrm{R}$ & Düz & Pembemsi \\
\hline 759-A-R & 2 & $\begin{array}{l}\text { Kompleks, Yuvarlak } \\
\text { (kabarık kenarlı) }\end{array}$ & $\mathrm{R}$ & Düz, Konveks & Krem, Sar1 \\
\hline 773-A-K & 1 & Buruşuk & $\mathrm{R}$ & Düz & Pembemsi \\
\hline 773-A-R & 1 & Buruşuk & $\mathrm{R}$ & Düz & Pembemsi \\
\hline P-1 & 1 & Yuvarlak (kabarık kenarlı) & $\mathrm{R}$ & Düz & Krem \\
\hline $\mathrm{P}-2$ & 1 & Yuvarlak & $\mathrm{S}$ & Konveks & Sarı \\
\hline DÜ-1 & 3 & Yuvarlak & $\mathrm{R}, \mathrm{S}$ & Düz, Konveks & Pembe, Sarı \\
\hline KA-1 & 3 & Yuvarlak & $\mathrm{R}, \mathrm{S}$ & Düz, Konveks & Sarıms1, Beyaz, Krem \\
\hline
\end{tabular}

Tablo 5. NA besiyerinde bakteri koloni morfolojisi

Arşiv odasından (Tablo 2, 3) izole edilen örneklerden Pseudonomas agar F base besiyerinde 759-A-K, 759-A-R, 773-A-K'da üreme görülmüş̧ür. Yapılan görsel inceleme (Resim 9) sonucunda 3 farklı koloni tespit edilmiştir (Tablo 6).
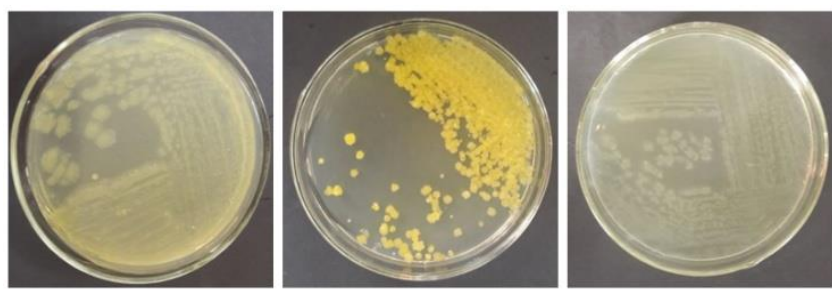

Resim 9. Pseudonomas agar F base besiyerinde 759-A-K, 759-A-R, 773-A-K (soldan sağa sirasıyla) görsel koloni morfolojisi 


\section{sanat}

\begin{tabular}{|c|c|c|c|c|c|}
\hline Örnekler & Koloni Çeşidi & Form & Kenar Tipi & Yükseklik \\
\hline $759-A-K$ & 1 & Düzensiz ve yayllıcı & R & Düz & Krem \\
\hline $759-A-R$ & 1 & Kompleks & R & Konveks & Sarı \\
\hline $773-A-K$ & 1 & Düzensiz ve yayılıcı & R & Düz & Şeffaf Krem \\
\hline
\end{tabular}

Tablo 6. Pseudonomas agar F base besiyerinde koloni morfolojisi

Arşiv odasından (Tablo 2, 3) izole edilen örneklerden EMB besiyerinde 759-A-K, 759-A-R, 773-A-K'da üreme tespit edilmiştir. Yapılan görsel inceleme (Resim 10) sonucunda 2 farklı koloni tespit edilmiştir (Tablo 7).
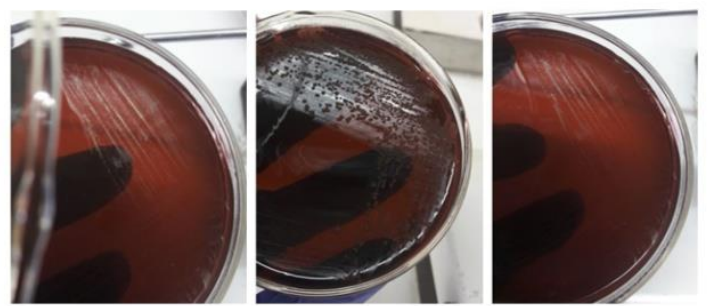

Resim 10. EMB besiyerinde 759-A-K, 759-A-R, 773-A-K (soldan sağa sırasıly) görsel koloni morfolojisi

\begin{tabular}{|c|c|c|c|c|c|}
\hline Örnekler & Koloni Çeşidi & \multicolumn{2}{c|}{ Form } & Kenar Tipi & Yükseklik \\
\hline $759-A-K$ & 1 & İğne ucu (pin- point) & S & Konveks & Metalik Yeşil \\
\hline $759-A-R$ & 1 & Yuvarlak & S & Konveks & Mor \\
\hline $773-A-K$ & 1 & İğne ucu (pin- point) & S & Konveks & Metalik Yeşil \\
\hline
\end{tabular}

Tablo 7. EMB besiyerinde koloni morfolojisi

EMB ve Pseudonomas agar $\mathrm{F}$ base besiyerlerine aktarılmış olup 759-A-K ve 773-A-K benzer ortamda birbirine en yakın koloni morfolojisi gösteren kültürler olduğu tespit edilmiștir. Ayrıca bu iki kültürün EMB besiyerinde laktozun fermentasyonuna bağlı olarak verdiği karakteristik metalik yeşil (Resim 11) renk nedeniyle Escherichia

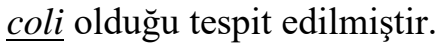
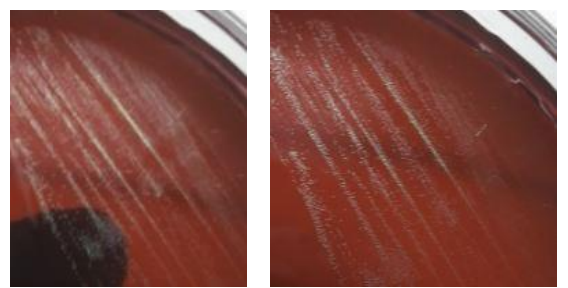

Resim 11. 759-A-K (solda) ve 773-A-K (sağda) tespit edilen Escherichia coli

\subsection{Eserlerden İzole Edilen Bakteri Örneklerinin Koloni Morfolojisi Sonuçları}

Eserlerden toplamda 12 adet izolasyon gerçekleștirilmiştir (Tablo 3). 773-E-1'de ise üreme tespit edilememiştir. Diğer örneklerin NA besiyerinde üremeleri görsel olarak incelenmiş (Resim 12) ve toplamda 12 farklı koloni tespit edilmiştir (Tablo 8). 


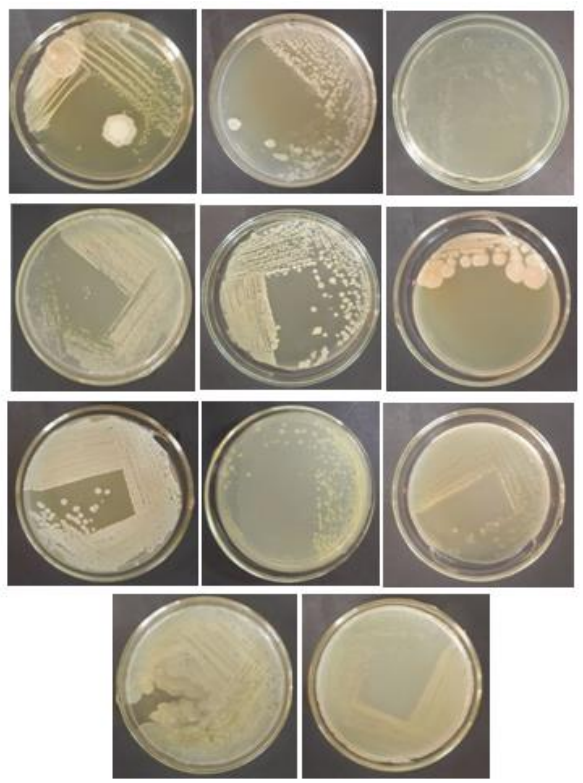

Resim 12. NA besiyerinde; 756-E-1, 756-E-2, 756-E-3 (birinci sıra soldan sağa); 756-E-K, 759-E-1, 759-E-2 (ikinci sira soldan sağa); 759E-3, 759-E-K, 773-E-2 (üçüncü sıra soldan sağa); 773-E-3, 773-E-K (dördüncü sıra soldan sağa) görsel koloni morfolojisi

\begin{tabular}{|c|c|c|c|c|c|}
\hline Örnekler & Koloni Çeşidi & Form & Kenar Tipi & Yükseklik & Rengi \\
\hline $756-\mathrm{E}-1$ & 3 & $\begin{array}{c}\text { Nokta, Yuvarlak } \\
\text { (kenarları tarakl1), } \\
\text { Buruşuk } \\
\end{array}$ & $\mathrm{R}, \mathrm{S}$ & $\begin{array}{l}\text { Kabarık, } \\
\text { Konveks }\end{array}$ & $\begin{array}{l}\text { Sarı, Krem, } \\
\text { Beyaz }\end{array}$ \\
\hline $756-\mathrm{E}-2$ & 1 & Buruşuk & $\mathrm{R}$ & Düz & Krem \\
\hline $756-\mathrm{E}-3$ & 1 & Düzensiz ve yayılıcı & $\mathrm{R}$ & Düz & Şeffaf Krem \\
\hline 756-E-K & 1 & Nokta & $\mathrm{S}$ & Konveks & Krem \\
\hline $759-\mathrm{E}-1$ & 1 & $\begin{array}{c}\text { Yuvarlak (kabarık } \\
\text { kenarlı) }\end{array}$ & $\mathrm{S}$ & Düz & Krem \\
\hline $759-\mathrm{E}-2$ & 1 & Yuvarlak & $\mathrm{R}$ & Konveks & Krem \\
\hline 759-E-3 & 1 & Buruşuk & $\mathrm{R}$ & Düz & Beyaz \\
\hline 759-E-K & 1 & Nokta & $\mathrm{S}$ & Konveks & Sar1 \\
\hline $773-\mathrm{E}-2$ & 1 & Nokta & $\mathrm{S}$ & Düz & Şeffaf Krem \\
\hline $773-\mathrm{E}-3$ & 1 & Kompleks & $\mathrm{R}$ & Düz & Krem \\
\hline 773-E-K & 1 & Nokta & $\mathrm{S}$ & Konveks & Krem \\
\hline
\end{tabular}

Tablo 8. NA besiyerinde bakteri kolonisi morfolojisi

Eserlerden (Tablo 3) eküvyon çubuklar ile alınan örneklerin Pseudonomas agar F base besiyerinde üremeleri görsel olarak incelenmiş (Resim 13) ve toplamda 10 farklı koloni tespit edilmiştir (Tablo 9). 


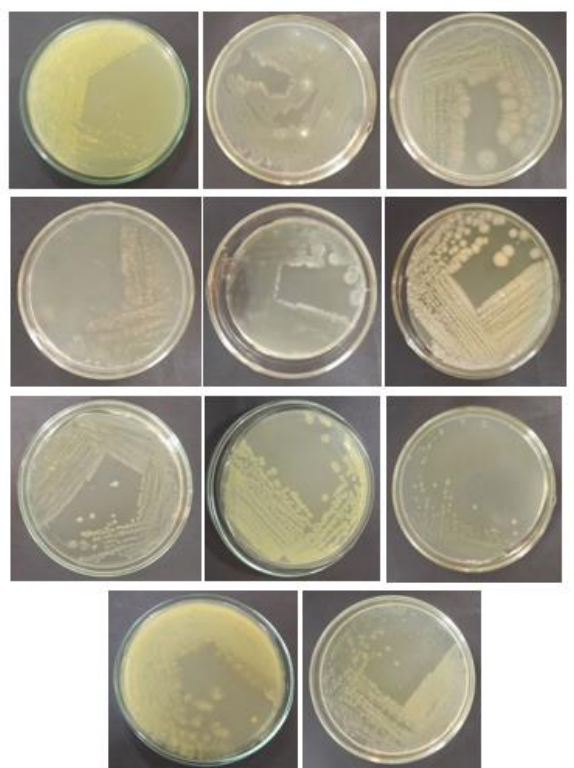

Resim 13. Pseudonomas agar F base besiyerinde 756-E-1, 756-E-2, 756-E-3 (birinci sıra soldan sağa); 756-E-K, 759-E-1, 759-E-2 (ikinci sıra soldan sağa); 759-E-3, 759-E-K, 773-E-2 (üçüncü sıra soldan sağa); 773-E-3, 773-E-K (dördüncü sıra soldan sağa) görsel koloni morfolojisi

\begin{tabular}{|c|c|c|c|c|c|}
\hline Örnekler & Koloni Çeșidi & Form & Kenar Tipi & Yükseklik & Rengi \\
\hline 756-E-1 & 1 & Nokta & $\mathrm{S}$ & Konveks & Sar1 \\
\hline 756-E-2 & 1 & Düzensiz ve yayılıc1 & $\mathrm{R}$ & Düz & Şeffaf Krem \\
\hline 756-E-3 & 1 & Düzensiz ve yayılıcı & $\mathrm{R}$ & Kabarık & Şeffaf Krem \\
\hline 756-E-K & 1 & Düzensiz ve yayılıc1 & $\mathrm{R}$ & Düz & Şeffaf Krem \\
\hline 759-E-1 & 1 & Burușuk & $\mathrm{R}$ & Düz & Şeffaf Krem \\
\hline 759-E-2 & 1 & $\begin{array}{c}\text { Yuvarlak (kabarık } \\
\text { kenarlı) }\end{array}$ & $\mathrm{R}$ & Konveks & Krem \\
\hline 759-E-3 & 1 & Nokta & $\mathrm{S}$ & Konveks & Krem \\
\hline 759-E-K & 1 & Yuvarlak & $\mathrm{S}$ & Konveks & Sar1 \\
\hline 773-E-2 & 1 & Nokta & $\mathrm{S}$ & Kabarık & Şeffaf Krem \\
\hline 773-E-3 & 1 & $\begin{array}{c}\text { Yuvarlak (kabarık } \\
\text { kenarlı) }\end{array}$ & $\mathrm{R}$ & Kabarık & Şeffaf Krem \\
\hline 773-E-K & 1 & Yuvarlak & $\mathrm{S}$ & Konveks & Krem \\
\hline
\end{tabular}

Tablo 9. Pseudonomas agar $\mathrm{F}$ base besiyerinde bakteri koloni morfolojisi

EMB besiyerinde 756-E-K, 759-E-1, 759-E-2, 759-E-3, 759-E-K'den elde edilen bakteri kültürlerinde üreme tespit edilmiştir. Üreme sonuçlara göre toplamda 3 farklı koloni morfolojisi (Resim 14) tespit edilmiştir (Tablo 10).
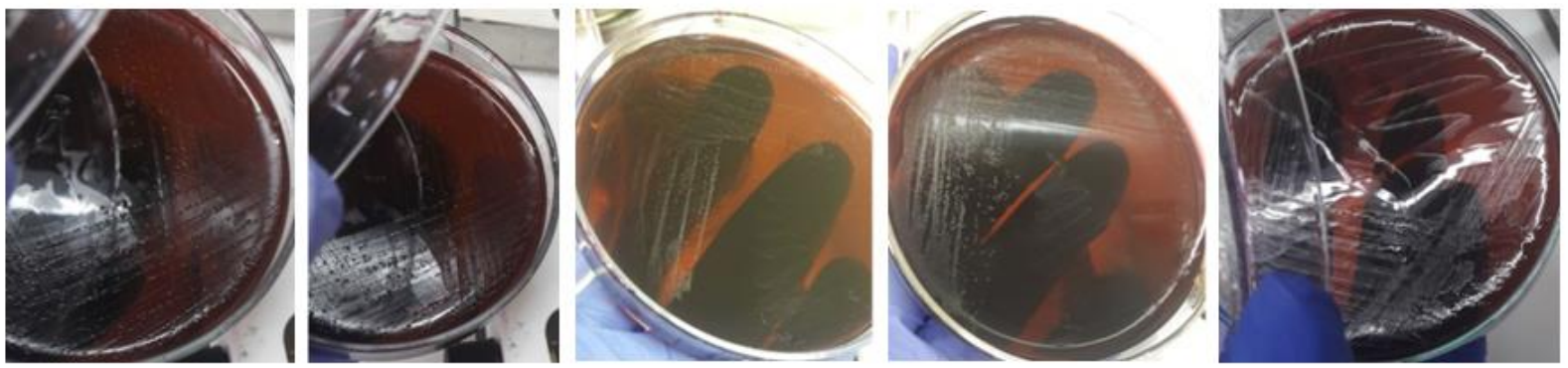

Resim 14. EMB besiyerinde 756-E-K, 759-E-1, 759-E-2, 759-E-3,759-E-K (soldan sağa sirasıly) görsel koloni morfolojisi 


\section{sanat}

\begin{tabular}{|c|c|c|c|c|c|}
\hline Örnekler & Koloni Çeşidi & Form & Kenar Tipi & Yükseklik & Rengi \\
\hline 756-E-K & 1 & Yuvarlak & $\mathrm{S}$ & Konveks & Mor \\
\hline 759-E-1 & 1 & Yuvarlak & $\mathrm{S}$ & Konveks & Mor \\
\hline 759-E-2 & 1 & $\begin{array}{l}\text { İgne ucu } \\
\text { (pin- point) }\end{array}$ & S & Konveks & Metalik Yeşil \\
\hline 759-E-3 & 1 & $\begin{array}{c}\text { İğne ucu } \\
\text { (pin- point) }\end{array}$ & $S$ & Konveks & Metalik Yeşil \\
\hline 759-E-K & 1 & Düzensiz ve yayılıcı & $\mathrm{R}$ & Düz & Mor \\
\hline
\end{tabular}

Tablo 10. EMB besiyerinde bakteri koloni morfolojisi

Kullanılan besiyerlerine göre üreme kapasiteleri ve morfolojilerinde farkl1lıklar gözlenmiştir. Tüm kültürler göz önüne alındığında; görsel olarak koloni morfolojilerinin incelenmesi sonucunda NA besiyerinde 22, Pseudonomas agar $\mathrm{F}$ base besiyerlerinde 13, EMB besiyerlerinde 3 olmak üzere toplamda 38 farklı koloni olduğu tespit edilmiştir (Tablo 11).

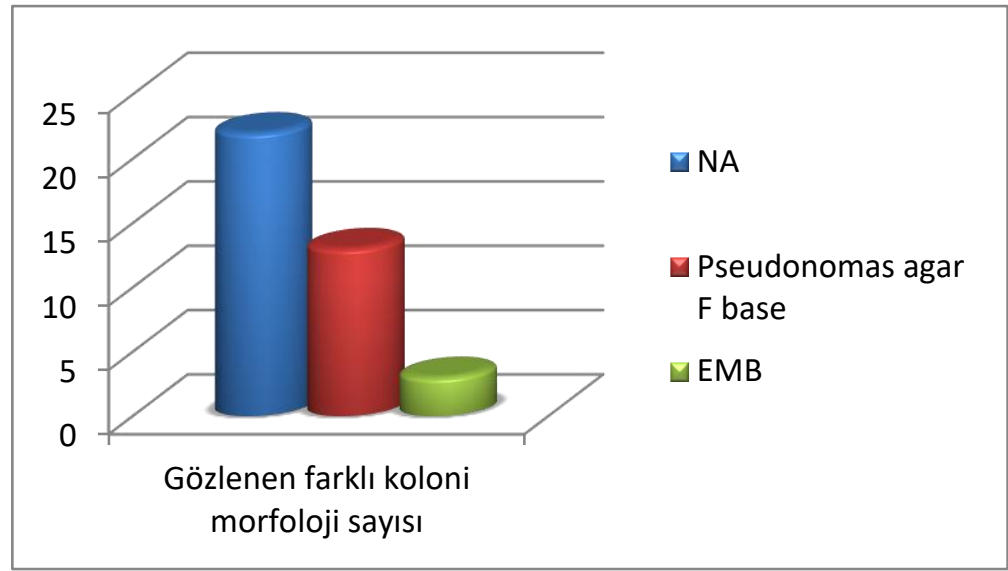

Tablo 11. Toplamda gözlenen koloni morfolojisi sonucu

Ayrıca elde edilen kültürlerin 21'inin düz (S- Tipi), 23’ünün dalgalı (R-Tipi) kenar tipine sahip koloni morfolojisi gösterdiği tespit edilmiştir. Pigment üretimlerine göre değerlendirildiğinde 9 farklı pigment üretiminin olduğu ve bunlardan 9'unun şeffaf krem, 15'inin krem, 3'ünün pembemsi, 1'inin pembe, 1'inin sarımsı, 8'inin sarı, 4'ünün beyaz, 4'ünün metalik yeşil, 4'ünün mor renkte olduğu tespit edilmiştir.

Koloni morfolojisine göre görsel olarak incelenen ve farklı olduğu gözlemlenen kolonilerden preparatlar hazırlanmış ve gram boyama işleminin ardından 100x'lik objektifte immersiyon yağı damlatılarak mikroskop altında incelenmiştir (Resim 15).
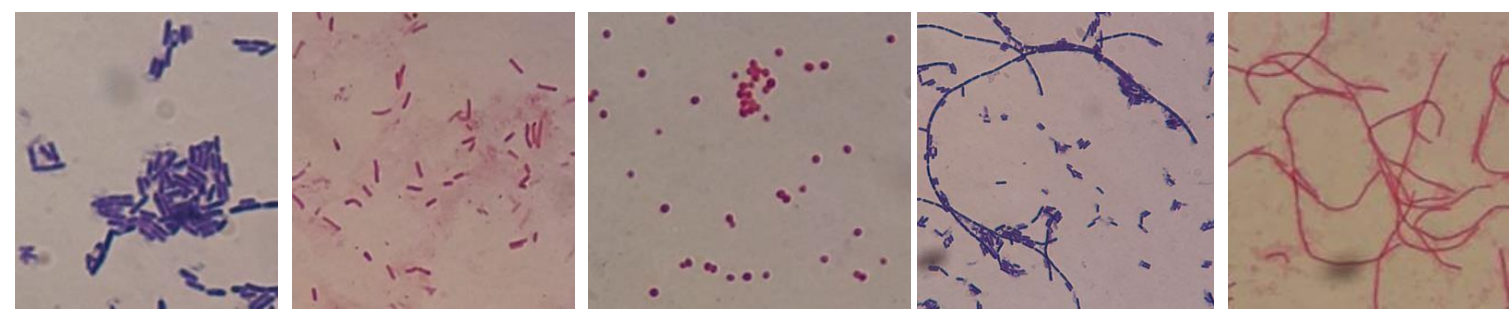

Resim 15. İzole edilen bakteri örneklerinin mikroskobik morfolojileri Gram (+) Basil, Gram (-) Basil, Gram (+) Kok, Gram (+) Streptobasil, Gram (-) Streptobasil (soldan sağa sirasılya)

Bakteri mikroflorası incelenmesi sonucunda 16 izolatın basil, 3 izolatın kok, 2 izolatın streptobasil olduğu tespit edilmiştir. Ayrıca 9'unun gram negatif, 13'ünün ise gram pozitif olduğu sonucuna varılmıştır (Tablo 12, 13). 


\begin{tabular}{|c|c|c|}
\hline Örnekler & Morfoloji & Gram Durumu \\
\hline $756-A-K$ & Basil & + \\
\hline $759-A-K$ & Basil & - \\
\hline $759-A-R$ & Basil & - \\
\hline $773-A-K$ & Basil & + \\
\hline $773-A-R$ & Basil & + \\
\hline P-1 & Basil & + \\
\hline P-2 & Kok & + \\
\hline DÜ-1 & Kok, & + \\
\hline KA-1 & Basil & \\
\hline
\end{tabular}

Tablo 12. Arşiv odası örnekleri mikroskobik inceleme sonuçları

\begin{tabular}{|c|c|c|}
\hline Örnekler & Morfoloji & Gram Durumu \\
\hline 756-E-1 & Streptobasil,Basil &,-+ \\
\hline $756-\mathrm{E}-2$ & Basil & - \\
\hline $756-E-3$ & Kok & + \\
\hline 756-E-K & Basil &,-+ \\
\hline 759-E-1 & Basil & - \\
\hline 759-E-2 & Streptobasil & - \\
\hline 759-E-3 & Basil & - \\
\hline 759-E-K & Basil & - \\
\hline $773-\mathrm{E}-2$ & Basil & - \\
\hline $773-\mathrm{E}-3$ & Basil & - \\
\hline 773-E-K & Basil & - \\
\hline
\end{tabular}

Tablo 13. Eserlerden alınan örneklerin mikroskobik inceleme sonuçları

\subsection{Fungus Örnekleri Makro ve Mikro Morfoloji Sonuçları}

Araştırma kapsamında eserden ve arşiv odasından alınan fungus kültürlerin koloni morfolojisi sonuçları Resim 16'da verilmiştir.
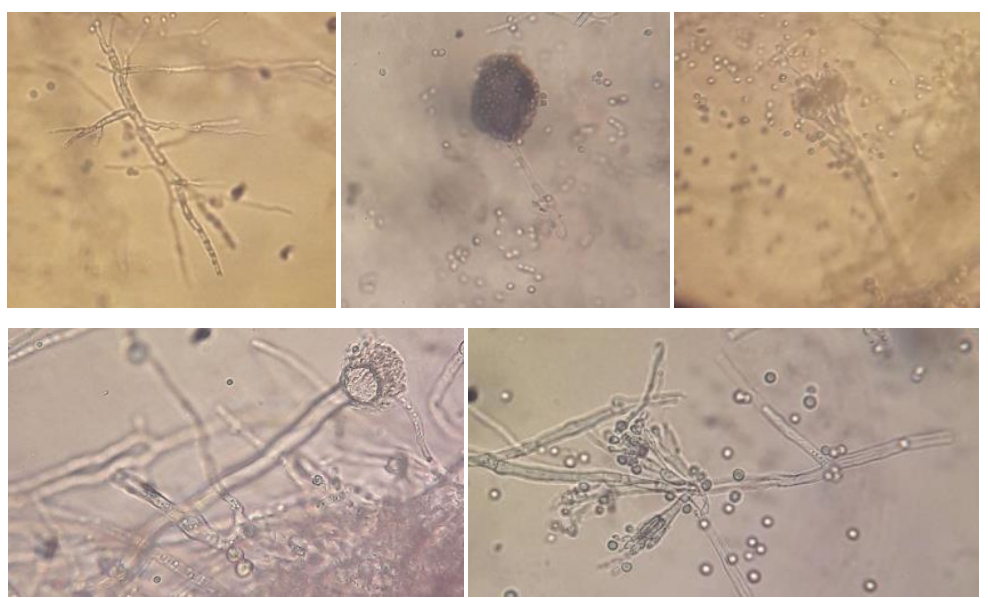

Resim 16. İzole edilen fungus örneklerinin Trichoderma sp, Mucor sp., Rhizopus sp. (birinci sıra soldan sağa) Aspergillus sp., Penicillum sp. (ikinci sıra soldan sağa) mikroskobik morfolojileri

Arşiv odasının fungus mikroflorasını belirlemek amacıyla (Tablo 1) birer adet yerleştirilen PDA besiyerlerinden elde edilen sonuçlara göre sadece dolap üstünde üreme görülmüş ve tek tip morfolojide koloni tespit edilmiştir. Yine arşiv odasında eserlerin doğrudan temas ettiği yüzeylerden (Tablo 2) ise 756-A-K, 773-A-K, 773-A-R'de üreme gözlenmiş ve toplamda 3 farklı morfolojide koloni tespit edilmiştir. Eserlerden izole edilen kültürlerden 
(Tablo 3) ise 756-E-1, 756-E-2, 756-E-K, 773-E-1, 773-E-2, 773-E-3, 773-E-K'de üreme gözlenmiş ve toplamda 11 farklı morfolojide fungus kolonisi tespit edilmiştir.

Araştırma kapsamında mikroskobik morfolojileri fungus kültürlerin vejetatif hif ve fertil (förtil) hif yapısına göre değerlendirilmiştir (Tablo 14).

\begin{tabular}{|c|c|c|c|}
\hline Örnekler & Cins & Vejetatif Hifler & Fertil Hifler \\
\hline $756-\mathrm{E}-2$ & Aspergillus sp. & Septasiz & Konidium \\
\hline 756-E-K & Penicillum sp. & Septalı & Konidium \\
\hline 756-A-K & Trichoderma sp. & Septal1 & Konidium \\
\hline 773-E-1 & $\begin{array}{c}\text { Mucor sp.(D), Penicillum } \\
\text { sp.(B), } \\
\text { Aspergillus sp.(A), } \\
\text { Rhizopus sp.(C) }\end{array}$ & Septasız, Septalı & $\begin{array}{c}\text { Sporangium (D) ve }(C), \\
\text { Konidium }\end{array}$ \\
\hline 7773-E-2 & Aspergillus sp. & Septasiz & Konidium \\
\hline 773-E-3 & Penicillum sp. & Septalı & Konidium \\
\hline 773-E-K & Penicillum sp. & Septalı & Konidium \\
\hline 773-A-K & Penicillum sp. & Septalı & Konidium \\
\hline 773-A-R & $\begin{array}{l}\text { Aspergillus sp. (A), } \\
\text { Penicillum sp. (B) }\end{array}$ & Septası,, Septalı & Konidium \\
\hline
\end{tabular}

Tablo 14. Fungus örneklerinin mikroskobik inceleme sonuçları

Araştırma kapsamında Mucor sp., Penicillum sp., Aspergillus sp., Rhizopus sp.,Trichoderma sp. cinsi küfler izole edilmiştir (Resim 16). Ayrıca DÜ-1 ve 756-E-1'de üreme olmuş fakat hif yapısı gözlenmediği için tanımlama yapılamamıştır.

\section{SONUÇ}

Vakıflar Genel Müdürlügü Ankara Kültür ve Tescil Daire Başkanlığı'nda muhafaza edilen Safranbolu El Yazmaları Koleksiyonundan seçilen Mushaf-1 Şerif eserlerin temas ettiği yüzeyler bakteriyolojik mikroflora açısından karşılaştırıldığında 756-A-K ile 756-E-K arasında her ikisinin NA'da ürediği fakat farklı koloni morfolojisine sahip olduğu gözlenmiştir. Ayrıca 756-E-K'nin EMB ve Pseudonomas agar F base besiyerlerinde üreme gözlenmesine rağmen 756-A-K'nin bu besiyerlerinde ürememesi bu iki izolatın ortak mikro floraya sahip olmadığı şüphesini uyandırmıştır. Fakat mikroskobik inceleme sonucunda her iki izolatta da gram pozitif basil gözlenmesi aynı cinsin farklı alt türleri (suşları) olabileceğini düşündürtmüştür. 759-A-K ile 759-E-K karşılaştırıldığında her iki kültürü 3 besiyerinde de ürediği fakat farklı koloni morfolojileri göstermesi nedeniyle farklı mikro floraya sahip olduğu şüphesini uyandırmıştır. Yine mikroskobik inceleme sonucuna bakıldığında bu sefer her iki izolatı gram negatif basil olarak gözlenmesi benzer şekilde aynı cinsin farklı alt türleri (suşları) olabileceğini düşündürtmüştür. Son olarak 773-A-K ile 773-E-K karşılaştırıldığında 773-A-K'nin her 3 besiyerinde de ürerken 773-E-K sadece NA ve Pseudonomas agar F base besiyerlerinde ürediği gözlenmiştir. NA ve Pseudonomas agar $\mathrm{F}$ base besiyerlerindeki koloni morfolojileri karşılaştırıldığında farklı koloni morfolojileri göstermeleri farklı mikro floraya sahip olduğu şüphesini uyandırmıştır. 773-A-K ile 773-E-K'nin mikroskobik olarak inceleme sonuçları da her iki izolatı gram negatif basil olması nedeniyle diğer sonuçlar ile paralellik göstermektedir.

Eserlerin temas ettiği yüzeyler fungus üremeleri bakımından karşılaştırıldığında ise 756-E-K'de Penicillum sp. cinsi küf izole edilirken 756-A-K'de ise Trichoderma sp. cinsi küf izole edilmiştir. Farklı cins küflerin izole edilmesi aralarında bulaş olmadığını kanıtlamaktadır. 773-E-K ve 773-A-K'nin her ikisinde ise Penicillum sp. cinsi küf izole edilmiştir. Bunlara ek olarak 773-A-R'de de Penicillum sp. cinsi küfün görülmesi aralarında kesinlikle bir bulaşın olduğunun göstergesidir.

Literatür taraması ile ülkemizde ve dünya genelinde kompakt raylı raf sisteminin arşiv malzemelerinin depolanmasında sıklıkla tercih edildiği sonucuna varılmıştır. Yapılan incelemeler göstermektedir ki, kompakt raylı raf sisteminin bulunduğu ortam ve kendisi arasında mikro klima farklılıklarının oluşması sonucunda bu sistem içinde depolanan arşivlerde sıklıkla Aspergillus sp. üremektedir. Nitekim bu sistem içinde depolanmakta olan araştırma kapsamındaki eserlerin 756-E-2, 773-E-1, 773-E-2, 773-A-R kültürlerinde görülen Aspergillus sp. daha önce yapılan araştırma sonuçlarını destekler niteliktedir. 
Araştırma kapsamında bir başka dikkat çeken husus da, arşiv odasında rafa yerleştirilen plaklarda üreme görülmezken; raftan eküvyon çubuğu ile alınan örneklerde üreme görülmesidir (Tablo 5-7, 10). Bu da göstermektedir ki, ya plakların rafta kalış süresi havadan spor toplamak için yeterli değildir ya da uygun koşullar oluşmadığı sürece dormanside kalacak türler bulunmaktadır. Nitekim, zenginleştirme besiyerleri kullanıldığında üreme gözlenmesi oradaki mikroorganizmaların varlığının biyolojik bozulma açısından potansiyel tehdit olduğu görüşünü destekler niteliktedir.

Yapılan araştırmalar, gram pozitif Bacillus sp.'nin çeşitli suşlarının bulunduğu ortamda bulunan Trichoderma sp. suşlarının üremesinde gerileme olduğu yönündedir. Araştırmada 756-A-K'den izole edilen bakterinin gram pozitif Bacillus sp., fungusun ise Trichoderma sp. olduğu göz önüne alındığında orada bulunan Bacillus sp.'nin antifungal ajan olduğu düşünülmektedir.

Araştırmalara göre gram negatif enterik basillerden Escherichia coli kolonileri, EMB besiyerinde laktozu hizlı fermentasyona uğrattığı için karakteristik bir metalik yeşil renk vermektedir. 759-E-2, 759-E-3, 759-A-K ve 773-AK'nin pasajlandığı EMB besiyerinde gözlemlenen bu metalik yeşil renk ve mikroskobik inceleme sonucunda gram negatif kokobasil olmaları nedeniyle bu kolonilerin $E$. coli olduğunu söylemek mümkündür. $E$. coli enterik bir bakteri olması ve aynı eserde birden fazla noktadan izole edilmesi, eserin daha önce ya sızdırma yapan bir gider borusunun altında depolandığını ya da sele maruz kaldığını göstermektedir.

Tüm bu veriler ışığında ele alınan örneklerin sonuçları göstermektedir ki, tarama alanı genişletilmeli; benzer sonuçlar gösteren tüm eserler diğer eserlerden uzaklaştırılmalı ve mümkün olan en kısa sürede etkin korumaya alınmalidır. 


\section{KAYNAKÇA}

Akkayan, C. (1987). Kağıt Üretiminde Mikrobiyolojik Problemler. İstanbul Üniversitesi Orman Fakültesi Dergisi, 37(2), 108-123.

Alexander, S. A., \& Schiesser, C. H. (2017). Heteroorganic Molecules and Bacterial Biofilms: Controlling Biodeterioration of Cultural Heritage. Organic chemistry, 180-222.

Baydar, N. (2001). Kütüphanelerdeki El Yazmalarının Pasif Konservasyonu. Türk Kütüphaneciliği, 15(4), 365-377.

Beguin, P. (1990). Molecular Biology of Cellulose Degradation. Annual Review of Microbiology, 44, 219-48.

Beguin, P., \& Aubert, J. P. (1994). The Biological Degradation of Cellulose. Federation of European Microbiology Societies (FEMS)Microbiology Reviews, 13(1), 25-58.

Börjesson, M., \& Westman, G. (2015). Crystalline Nanocellulose - Preparation, Modification, and Properties. In M. Poletto (Eds.), Cellulose: Fundamental Aspects and Current Trends. Croatia: BoD - Books on Demand, pp. 159- 189.

Carlo, E. D., Barresi, G., \& Palla, F. (2017). Biodeterioration. In G. Barresi, F. Palla (Eds.), Biotechnology and Conservation of Cultural Heritage. Switzerland: Springer International Publishing, pp. 1-31.

Chen, H. (2014). Biotechnology of Lignocellulose: Theory and Practice. Chemical Industry Press, Beijing and Springer Science Business Media Dordrecht.

Dunca, I. S., Tanase, C., Padurariu, C., Balaes, T., Ardelean, E., \& Puica, M. N. (2014). Study of the Contaminating Microbiota of Old Paper Supports. European Scientific Journal September, 3, 237-251.

Hagaggi, A., \& Salah, T. A. (2016). Microbial Deterioration of a 13 AH-Century Manuscript Housed in Al-Azhar Library in Egypt: A Case Study. Journal of Basic and Environmental Sciences, 3, 65-73.

Halkman, A. K. (2005). Merck Gıda Mikrobiyolojisi Uygulamaları. Ankara: Başak Matbaacılık Ltd. Şti.

Heldt, H. W., \& Piechulla, B. (2011). Plant Biochemistry. Fourth edition. USA: Academic Press is an imprint of Elsevier.

Gallo, P. (1953). Considerazioni Sui Rapporti Tra i Funghi Ospiti della Carta e le micosi Umane. La Soprintendenza archivistica e bibliografica.

Karakasidou, K., Nikolouli, K., Amoutzias, G. D., Pournou, A., Manassis, C., Tsiamis, G., \& Mossialos, D. (2017). Microbial Diversity in Biodeteriorated Greek Historical Documents Dating Back to the 19th and 20th Century: A Case Study. Microbiology Open, 7(5), 111 .

Kathpalia, Y. P. (1990). Arşiv Malzemesinin Korunması ve Restorasyonu. (Çev. N. Somer), T.C. Başbakanlık Devlet Arşivleri Genel Müdürlüğü, Cumhuriyet Arşivi Dairesi Başkanlığı, Yayın No:6, Ankara: Başbakanlık Basımevi (Eserin orijinali 1973'te yayımlandı).

Khazraji, A. C., \& Robert, S. (2013). Interaction Effects between Cellulose and Water in Nanocrystalline and Amorphous Regions: A Novel Approach Using Molecular Modeling. Journal of Nanomaterials, 1-10.

Koca-Yılmaz, A. S. (2019). Vakıflar Genel Müdürlüğ̈̈ Ankara Kültür ve Tescil Dairesi Başkanllğg Arşivine Ait Yazma Eserlerin Korunmasına Yönelik Biyodeterasyon Tespiti. Yayımlanmamış Yüksek Lisans Tezi, Gazi Üniversitesi Güzel Sanatlar Enstitüsü, Ankara.

Koca Yılmaz, A.S., Akın, A. A., \& Katırcıoğlu, H. (2020). El Yazmalarında Görülen Biyodeterojenler ve Sağlığa Etkileri. T.C. Kültür ve Turizm Bakanlığı Kültür Varlıkları ve Müzeler Genel Müdürlüğü 41. Uluslararası Kazı, Araştırma ve Arkeometri Sempozyumu, 1721 Haziran 2019. 35. Arkeometri Sonuçları Toplantısı, T.C. Kültür ve Turizm Bakanlığı Kültür Varlıkları ve Müzeler Genel Müdürlüğü Yayın No:3656/189, Diyarbakır, Türkiye, s. 43-50.

Kuhad, R. C., Kuhar S., Kapoor M., Sharma K. K., \& Singh A. (2007). Lignocellulolytic Microorganisms, their Enzymes and Possible Biotechnologies based on Lignocellulolytic Microorganisms and their Enzymes. In Kuhad, R.C., Singh A. (Eds.), Lignocellulose Biotechnology: Future Prospects. New Delhi: IK International Publishing House Pvt. Ltd, pp. 3-23.

Michaelsen, A., Pinar, G., Montanari, M., \& Pinzari, F. (2009). Biodeterioration andrestoration of a 16th-century book using a combination of conventional and moleculartechniques: a case study. International Biodeterioration \& Biodegradation, 63(2), 161-168.

Michaelsen, A. (2010). Foxing of Paper Caused by Fungi and Molecular Monitoring of Conservation Treatments Naturwissenschaften. Unpublished PhD Thesis, University of Vienna, Italy.

Nianping, L., Jinhua, H., Binghua, L., \& Lijie, W. (2011). Indoor Mildew Pollution in Building and Control Strategies, Paper. Presented at the Third International Conference on Measuring Technology and Mechatronics Automation, Shanghai.

Perez, J., Munoz-Dorado, J., Rubia, T., \& Martinez, J. (2002). Biodegradation and Biological Treatments of Cellulose, Hemicellulose and Lignin: An Overview. International Microbiology, 5(2), 53-63.

Pinar, G., Sterflinger, K., \& Pinzari, F. (2013). The Microflora Inhabiting Leonardo da Vinci's Self Portrait: a Fungal Role in Foxing Spots. Paper Presented at the Paper Conservation: Decisions \& Compromises, ICOM-CC Graphic Documents Working Group Interim Meeting, Vienna.

Rojas, T. I., Martinez, E., Gomez, Y., \& Alvarado, Y. (2002). Airborne Spores of Aspergillus Species in Cultural Institutions at Havana University. Grana, 41(3), 190-193. 
Ruiz, C. C., Avendano, R., Leyva, E. E., Barboza, C. G., Chaverri, P., \& Chavarria, M. (2018). Two New Cellulolytic Fungal Species İsolated from a 19th-Century Art Collection. Scientific Reports, 8(7492), 1-9.

Sanchez-Silva, M., \& Rosowsky, D. V. (2008). Biodeterioration of Construction Materials: State of the Art and Future Challenges. Journal of Materials in Civil Engineering, 20(5), 352-365.

Sterflinger, K., \& Pinar, G. (2013). Microbial Deterioration of Cultural Heritage and Works of Art Tilting at Windmills?. Applied Microbiology and Biotechnology, 97(22), 9637- 9646.

Sterflinger, K., \& Pinzari F. (2012). The Revenge of Time: Fungal Deterioration of Cultural Heritage with Particular Reference to Books, Paper and Parchment. Environmental Microbiology, 14(3), 559-566.

Ünlü-Yokuş, Y. (2018). Yazma Eserlerin Mikrobiyolojik Kontaminasyon Yönünden İncelenmesi. Yayımlanmamış Yüksek Lisans Tezi, İstanbul Üniversitesi Fen Bilimleri Enstitüsü, İstanbul.

Wisniak, J. (2005). Anselme Payen. Educación Química, 16(4), 114-126. 